\title{
The human capital theory. Encouragement and criticism
}

\section{Uliana Kolomiiets}

Ph.D. Candidate, CERGE-EI, a joint workplace of Charles University and the Economics Institute of the Czech Academy of Sciences, Czech Republic

\section{Yuriy Petrushenko}

Doctor of Economics, Head of the Department of International Economics, Sumy State University, Ukraine

(C) The Authors, 2017. This article is published with open access at ARMG Publishing.

\begin{abstract}
What is a human capital? Many minds tried to find answer for this question. First attempts were made even during the ancient times. However, as it is mentioned in the early scientific literature, human capital as a determinant in labor economics appeared at the end of XX century. Until recently it is one of the most discussed questions in the field. Therefore, this work will present thoughts of many famous economists who have made any contribution into human capital. Moreover, there is a connection that goes through years and centuries showing the main points of dispute and compares it with points of current hot debates. It might help to understand current problems better, because we have to "explore the past to understand the present and shape the future" (Graseck, 2008).
\end{abstract}

Keywords: human capital, Mincerian theory, labor economics, income distribution, factor of production, human capital investment, returns, criticism, encouragement.

\section{JEL Classification: J24.}

\section{Introduction}

An economic history consists of the multitude of names, facts, theorems, studies, etc. Considering the fact that human capital is an integral part of many different economic determinants (income, capital, life cycle and so on), there is a plenty of thoughts about the question of interest.

Therefore, to do this work as much efficient as it is possible, a study of Mincer (1958) and his interpretation of human capital will be used as a base. Precisely, he created a model for measuring an investment into human capital.

As a starting idea he used personal income dispersion, which he described using Pigou explanation of income dispersion paradox. It says that there is a normal distribution of abilities with a sharply skewed distribution of income (when we should expect to get normally distributed income). Mincer mentioned that non-economic factors play crucial role in the distribution of income. Therefore, in order to verify the impact of human characteristics on the income the model uses an assumption that all agents have identical abilities and, moreover, different occupation requires different level of trainings. Training takes time and each additional year of it postpones the individal's earnings for another year, generally reducing the span of his earning life. If individuals with different training level are to be compensated for the costs of training, the present values of life-earnings must be equalized at the time a choice of occupation is made. Mincer proposed to take into account income receipts which are the same each year during the whole life.

Therefore, it is possible to estimate the extent of compensatory income differences due to differences in the cost of training. Alternatively, we can estimate the cost made into human capital, which increases income dispersion. Eventually, Mincerian model allows to estimate human capital investment.

Mincer became a father of labor economics and his theories including human capital theory are taken as a base. However, the question about human capital is still open and a lot of economists are working on it. This paper is aimed to discuss critics and supports of Mincerian theory which have been done by famous economists who dealt with human capital.

The article is built as follows: there are two main parts, one with supports of theory, presented by Smith, Pigou, Fisher and Schultz, another with its criticism, presented by Mill and Marshal. 


\section{Encouragement}

\section{Adam Smith}

However, what do economists think about human capital years and centuries ago? It would be proposed to start from Adam Smith (Scottish moral philosopher and a pioneer of political economy). Despite the fact, that he is the most famous economist, he made a huge contribution into the human capital development like a separate determinant in labor economics. Moreover Smith distinguished human capital from labor as a factor of production. In his book "An Inquiry into the Nature and Causes of the Wealth of Nations" published in 1776 we can find: "Fourthly, of the acquired and useful abilities of all the inhabitants or members of the society. The acquisition of such talents, by the maintenance of the acquirer during his education, study, or apprenticeship, always costs a real expense, which is a capital fixed and realized, as it were, in his person. Those talents, as they make a part of his fortune, so do they likewise that of the society to which he belongs. The improved dexterity of a workman may be considered in the same light as a machine or instrument of trade which facilitates and abridges labor, and which, though it costs a certain expense, repays that expense with a profit." Therefore, Adam Smith noticed that it is necessary to take into account all workers characteristics (education, ability, talent) which have a significant impact on the output. Therefore, his statement shows the necessity of human capital as an important production factor. Moreover, the higher education requires higher costs. On the other hand, the higher education increases worker's productivity, in turns, it increases output. In "...Wealth of Nations" one can find "... a man educated at the expense of much labor and time to any of those employment which require extraordinary dexterity and skill, may be compared to one of those expensive machines. The work which he learns to perform, it must be expected, over and above the usual wages of common labor, will replace to him the whole expense of his education..." Thus, it is possible to use income as a payment for training costs. Therefore, as well as Mincer, Smith defined human capital and mentioned that the higher investment into human capital the higher the income the person might get. Thus, Adam Smith's study made a huge contribution into the human capital investment as well as into the theory of human capital as a production factor.

\section{Arthur Cecil Pigou}

The next famous name that was referred in Mincer's study is Arthur Cecil Pigou (English economist). In his book "The Economics of Welfare" (1932) he dealt with income dispersion. As it was mentioned before, he is an author of personal income dispersion paradox (normal distribution of abilities does not lead to normal income distribution). Pigou explained this with "income determining factors other than ability", which destroys the relationship between abilities and income. Therefore, Pigou stated that there exist observable as well as unobservable person's characteristics which have an impact on agent's income and which causes skewness of its distribution. Speaking about human capital investment, according to W. Arthur Lewis (1954), the term "human capital" was not used because of its negative undertone until it was discussed by Pigou. He stated that in parallel with the investment into the material capital there is such thing as investment into the human capital. Pigou explained this as an investment into the consumption. He stated that "consumption is investment in personal productive capacity". Moreover, the author pointed out importance of such investment into children. If parents decrease spendings on their child, it might have bad impact on their "after-childhood" period. Despite the situation of luxury life, the same logic is applicable to adults. Therefore, Pigou's study about income dispersion became a base for Mincerian model. However, his explanation of human capital investment differs crucially from the common one. However, on the other hand, thanks to Pigou we have got study which is called "human capital".

\section{Irving Fisher}

Searching thought a history of human capital development, it was found a very interesting explanation, given by Irving Fisher (American economist, statistician, inventor, and progressive social campaigner). In his book "The Nature of Capital and Income" (1906) he stated that a concept of capital should include: land and other natural resources..., objects owned by household and government..., the bodies of human beings -perhaps theirs mind too - as well as non-human objects (it was used "Commentary on Irving Fisher, The Nature of Capital and Income" (1906) by James Tobin, 1991). However, economic schools were not agreed with such deviation from classical theory for production factors classification: labor, land, capital. Additionally, perhaps because of Irving Fisher's health problem (he had tuberculosis) he pointed out one of the main factor of economic development is a human health: "A large part of our subjective income is due to our condition of health or disease. A man with a good constitution has a more agreeable stream of consciousness than one without... 
healthy body is absolutely essential for receiving and enjoying the income from external wealth... Economists, by fixing attention by physical phenomena leave out the most essential element of all, the vigor of human life. The true "wealth of nations" is the health of its individuals" (1906, p. 176). Thus, we can see that Fisher made a significant contribution into the question about human health as a part of human capital which has significant impact on productivity of the country. In contrast, Mincer did not mention any of health characteristic, however, the model created in a way to include all costs in human capital investment.

\section{Theodor W. Schultz}

Likewise, Theodor W. Schultz (American economist) carefully described human capital and gave explanation to human capital investment in his paper "Investment in Human Capital" (won a Nobel Prize for contribution in the field). He defined a human capital as a determinant of qualitative characteristics of human resources, which includes knowledge, skill and similar attributes that affect particular human capabilities to do productive work. Moreover, an investment into the human capital are spends which are distributed between such human activities which increases productivity. Schultz concentrated on five categories: health, education, onthe-job training, study programs for adults and migration of individuals and families. However, the author underlined that there is underinvestment into human capital. For instance, some countries put education on a level of culture; therefore, people consume it as a non-material good. However, Schultz stated that there are no models which can estimate human capital investment. The strange here is the chronology of the studies: Mincer wrote his article in 1958 and Schultz in 1961. Either of them did not use references of each other (both of them were living in USA at that time). Perhaps the reason was 20 years difference in their age (for Schultz it was not prestigious to work with younger but more successful Mincer). Likewise, both of them used almost the same literature supports (Pigou, Smith, etc.). It is very interesting fact of possible competition between scientists. In any case, Schultz was the Nobel Memorial Prize winner in Economic Sciences in 1979 and Mincer has got a name of father of modern labor economics.

\section{Criticism}

\section{John Stuart Mill}

Returning to the development of human capital, it is necessary to mention about those studies which did not confess Human Capital per se. The earliest critique about human capital was made by John Stuart Mill's (English philosopher, political economist and civil servant) work "Principles of Political Economy with some of their Applications to Social Philosophy (Ashley ed.)" (1848), that the people of a country should not be looked upon as a wealth of this country "because wealth existed only for the sake of people", and investment into studying, trainings and other improvements were deliberated as huge spending made by family or government. This spending was not included into production costs. However, according to Schultz, it was the main mistake of economists which were accompaniment with misinterpretation of this spending and taking into account just human capacity (human labor which gives output).

\section{Alfred Marshall}

The second name who did not confess human capital as a production factor was Alfred Marshall (British economist). He presented a stream of ideas that capital is "neither appropriate nor practical to apply" for human beings, because it cannot be taken as a treatment in the practical analyses. Moreover, Marshall as well as his followers did not recognize investment into human capital as a production costs ("investments in human beings have seldom been incorporated in the formal core of economics"). Therefore, Alfred Marshall did not want to define "human capital" per se; however, he realized that human beings play crucial role in labor economics. Even though, my own search show that on the one hand Marshall defined "human capital" as nonmaterial agent's good (ability, skills, education, business connections, person's openness, etc.). On the second hand, later he pointed out that capital-investment includes costs of parents for education, rearing and training of their offspring. This spending is a part of costs for labor production factor (needs to be mentioned that Marshal defined two types of production factors: capital (included land) and labor). Likewise, such investments have returns in wage. However, there are two sources of costs (children put effort into studying and parents invest time and money), but there is just one return. Thus, according to Marshall, this is a description of parenthood (parents need to share theirs wage in a way to decrease/minimize disutility of child's studying in order to help/stimulate child to get higher level of education) (see Alfred Marshall "Principles of Economics", $8^{\text {th }}$ ed., 1890 and H.J. Davenport "The Economics of Alfred Marshall", 1965). Therefore, we can notice that Marshall described "indirect" investment into human capital. It means that he noticed and included costs of education and increasing skills into labor production factor costs, however, he did it through the third side - parents of children. 


\section{Conclusions}

As it was mentioned in the beginning, nowadays human capital is still a very popular topic to discussion among economists. There is a lot of theoretical and empirical papers, which basically were built on the Mincerian model. However, in contrast, there is a plenty of critical studies. Having analyzed few of such articles, we found very interesting fact, that most of them critique exactly Shultz determination of human capital as a qualitative attribute of human resource. Further, it becomes the main characteristic of human capital. Such description becomes widely used in macroeconomic theory; especially neoclassical economists start to use it in order to investigate an economic growth.

However, it is not possible to aggregate quality characteristic to macro level. To do so, all quality characteristics should have the same dimensions. For instance, it is not possible to aggregate years of education in Harvard and years of education in University of Phoenix, because it shows completely different qualities of education. Furthermore, the same number of education would give totally different returns on it. As a result, does it mean that the human capital cannot be measured in macro level? Therefore, we can conclude that human capital might be described just on the individual's level or is it a determinant which is not possible to measure and estimate?

This is exactly a question which we asked ourselves when we faced with human capital interpretation. However, Mincerian model helps to understand the general picture and has a point taking the difference between earnings and observable costs for training as human capital investment. Unfortunately, currently we still do not have efficient solution to the question how to measure a human capital.

\section{References}

1. Chiswick, Barry R. (2003). Jacob Mincer, Experience and the Distribution of Earnings. IZA Discussion Papers 847, Institute for the Study of Labor (IZA).

2. Mincer, J. (1958). Investment in Human Capital and Personal Income Distribution. Journal of Political Economy, University of Chicago Press, 66, 281 p.

3. Smith, Adam (1776). An Inquiry into the Nature and Causes of the Wealth of Nations 1 (1 ed.). London: W. Strahan. Retrieved on May 9, 2017 from http://books.google.bg/books?id=mt1SAAAAcAAJ\&pg= $\mathrm{PP} 4 \# \mathrm{v}=$ twopage $\& \mathrm{q} \& \mathrm{f}=$ true.

4. Pigou, Arthur C. (1932). The Economics of Welfare. Library of Economics and Liberty. Retrieved May on 9, 2017 from http://www.econlib.org/library/NPDBooks/Pigou/pgEW.html.

5. Lewis, W. Arthur (1954). Economic Development with Unlimited Supplies of Labor. Manchester School of Economic and Social Studies, 22, 139-191.

6. Fisher, I. (1906). Nature of capital and income. New York. Maximillan.

7. Schultz, Theodore W. (1961). Investment in Human Capital. American Economic Review, 51(1), 1-17.

8. Tobin, James (1991). Commentary on Irving Fisher, The Nature of Capital and Incme (1906). Cowles foundation discussion paper no. 992. Cowles foundation for research in economics at Yale University.

9. Marshall, Alfred. (1920). Principles of Economics. Library of Economics and Liberty. Retrieved on May 9, 2017 from http://www.econlib.org/library/Marshall/marP.html.

10. Davenport, H.J. (1965). The Economics of Alfred Marshall. Augustus M. Kelley, New York. 